\title{
Artigo
}

\section{Dos zebus e seus clones: valor e pedigree em um mercado de elite}

\author{
Natacha Simei Leal \\ Universidade Federal do Vale do São Francisco, São Raimundo Nonato, Piauí, PI, Brasil \\ natachaleal@gmail.com
}

RESUMO: O Brasil comercializa os bovinos de "elite" de origem zebu (da subespécie Bos taurus indicus) - modelos raciais, estéticos e reprodutivos, com pedigree - mais caros do planeta, além disso, através de "parcerias" entre Estado, fazendeiros e laboratórios privados, está à frente no uso e pesquisa de biotecnologias (inseminação artificial, fertilizações in vitro, clonagens) para produzir esses animais. No ano de 2002, a Embrapa realizou um procedimento bem-sucedido de transferência nuclear. Desde então, fazendeiros que investiram em pesquisas experimentais na técnica, passaram a produzir e comercializar clones de importantes reprodutores. Em 2007, um clone da "doadora" Bilara VII, a vaca Ópera, da raça Nelore, foi comercializado por um milhão de reais em um leilão. Apesar das altas cifras pagas pelo animal, ele não pode receber pedigree; na época, nem a Associação Brasileira dos Criadores de Zebu (instituição que controla os padrões raciais e o fornecimento de registros genealógicos de espécimes zebuínos no Brasil), tampouco o Ministério da Agricultura, conseguiram lidar com as controvérsias que Ópera mobilizava: indubitavelmente, ela era "de elite", mas quem eram, de fato, seus progenitores? Este artigo, através da descrição das controvérsias envolvendo os primeiros procedimentos de transferência nuclear e comércio de bovinos clonados país - pelos laboratórios e em leilões - pretende iluminar a produção e realização do mercado de gado de "elite" brasileiro. Anseia discutir sobre a centralidade da ideia de pedigree na pecuária zebuína, os efeitos do uso de tecnologias reprodutivas, a coalizão de interesses entre empresariado rural e Estado no Brasil, além de refletir sobre o estatuto e valor de bovinos e criadores de "elite".

PALAVRAS-CHAVE: agronegócio, clonagem, elite, pecuária, pedigree. 
O Professor Ian Wilmut, do Instituto Roslin, na Escócia, publicou um artigo na Revista Nature, "Viable Offspring Derived from Fetal and Adult Mammalian Cells" (1997), que trouxe à tona resultados de pesquisas que vinha realizando desde o início da década de 90 . O texto era a comunicação oficial do nascimento em 1996 da ovelha Dolly.

Resumidamente, através da biotecnologia de transferência nuclear, Wilmut inseriu células congeladas de uma ovelha da raça Finn Dorset em um óvulo (vazio) de outra fêmea - da raça Schottisch Blackface. Estas células - de um animal adulto - que, ao serem fundidas nesse óvulo vazio através de correntes elétricas se dividiram tal como células germinativas, se transformaram em um embrião, que foi gestado no corpo de uma terceira ovelha (uma barriga de aluguel), também da raça Finn Dorset. A experiência de Wilmut, que fez Dolly - e, logo, todas as controvérsias e efeitos que clonagem veio a gerar - produziu um indivíduo semelhante no genoma e no fenótipo com a ovelha doadora das células que deram origem a ela.

A antropóloga Sarah Franklin (2007), ao pensar a trajetória de Dolly, defende que a ovelha colocou em cheque conceitos e premissas da ciência, da política, das técnicas, do parentesco, da economia. Tanto por ela ser um clone - uma réplica de outra ovelha -, mas também por tudo aquilo que a clonagem representa: a possibilidade de uma mutação no tempo, nas gramáticas da reprodução e da descendência, nas certezas da domesticação e do controle biológico. Segundo Franklin, Dolly produziu efeitos em muitas searas, articulou interesses da agricultura, do comércio, da medicina, da indústria.

Antes de Dolly, os estudos sobre genes - entendidos como uma unidade fundamental capaz de expressar informações - ocupavam posição privilegiada na biologia. Com o nascimento da ovelha, ocorre uma abertura a novas pesquisas com células (é com elas que se realizam as técnicas de transferência nuclear). A possibilidade de produzir animais a partir de tecidos (de células de glândulas mamárias ou da orelha) tornou a reprodução mais flexível e eficiente. Além disso, prossegue Franklin, Dolly, a prole da "ciência pura", é efeito de cruzamentos híbridos, em mais de um sentido. Ela fez emergir a necessidade de articulação de saberes da genômica, da informática e da biologia molecular; foi feita por meio de uma parceria "público-privado"; e só foi possível, de outro ponto de vista, por conhecimentos acumulados da antiga tradição britânica - capitaneada por figuras como Robert Bakewell, inventor do inbreeding, e mesmo de Charles Darwin - de experimentações, seleções dirigidas e publicação de pedigrees de animais domésticos.

Não foi sem razão, por exemplo, que Wilmut, um escocês, teria clonado uma ovelha, segundo Sarah Franklin. Na Grã-Bretanha, há uma longa tradição na criação, comércio, 
“raceamento" e melhoramento desses animais para a indústria (da carne e do leite) e mesmo para a ocupação das colônias. Quando realizou os primeiros procedimentos que acabaram por dar origem à Dolly, o Professor Wilmut estava interessado em produzir animais leiteiros transgênicos. Para isso, escolheu ovelhas de raças britânicas. Através da lactação, queria produzir um sistema capaz de extrair proteínas do leite utilizáveis pela indústria farmacêutica no estudo de doenças e disfunções metabólicas congênitas.

Há um consenso entre cientistas, a partir do êxito da experiência que gerou Dolly, que a clonagem de mamíferos pode contribuir tanto com a ciência básica - nos estudos de desenvolvimento embrionário, de reprogramação molecular e células tronco - na conservação animal - através de bancos de sêmen e embriões de espécimes em via de extinção - e na produção animal - multiplicação de espécimes de elevado mérito genético, como são os bovinos "de elite".

Em larga medida, é em virtude dessa última razão que o Brasil, desde o início dos anos 2000, está à frente de pesquisas com a técnica. Vale lembrar que Ian Wilmut, em uma passagem do livro Dolly, a segunda criação e a era do controle (2000), ao narrar a história de seu grande feito, conta que com a clonagem da ovelha alguns cientistas ficaram especialmente entusiasmados com a possibilidade de replicar animais "de elite". E isso também entusiasmou veterinários, zootecnistas e pecuaristas brasileiros. O país não é apenas um dos maiores produtores de carne bovina do mundo, mas produz os zebus "de elite" mais caros do mundo. A clonagem pode, segundo criadores e cientistas, alavancar essa indústria

\section{O mercado de gado de elite}

Uberaba, localizada no Triângulo Mineiro, concentra os principais criatórios de gado "de elite" do Brasil. Uma matéria publicada na Revista Globo Rural em abril de 2013 deu ao trecho da BR050 que liga a cidade à vizinha Uberlândia e ao estado de São Paulo, duas alcunhas: "Vieira Souto do Zebu" " e "Vale do Sêmen". São nas fazendas, laboratórios e centrais de inseminação artificial localizados nessa estrada que os bovinos mais caros do mundo são produzidos.

Mas Uberaba, além de sediar a Associação Brasileira dos Criadores de Zebu (ABCZ), a instituição responsável pelo controle racial e emissão dos pedigrees de espécimes zebuínos no Brasil, não produz exatamente bovinos que são encaminhados para o abate. A partir da década de sessenta do século xx, a região Centro-Oeste tornou-se a maior produtora de gado 
comercial do país, não coincidentemente zebus, da raça Nelore, e contemporaneamente a pecuária bovina avança a passos largos na Amazônia.

As reses desenvolvidas em Uberaba habitam "cocheiras" e não pastos. Têm pedigree, são nobres e muito raramente são abatidas. Superalimentadas com uma ração de alto índice proteico, banhadas e penteadas cotidianamente, são mais avistadas nas “pistas" dos julgamentos ou leilões e nos pavilhões de exposição das feiras de pecuária, que nos campos das fazendas. Uberaba, mais que a sede de laboratórios, fazendas e feiras agropecuárias especializadas em gado zebu, é a sede de um projeto de invenção de uma pecuária de elite nacional.

Um espécime de "elite" é um reprodutor, deve ser dotado de um conjunto de características raciais - fenotípicas e genotípicas - consideradas exemplares. Através do uso contínuo desses "raçadores" em acasalamentos dirigidos, espera-se que um tipo racial inteiro seja aprimorado. Estes animais ajudam a engendrar uma indústria - que no Brasil atualmente se destaca em Uberaba - de "estoque de sangue e pedigree”. São fornecedores, por excelência, de substâncias - sangue, genes, sêmen, ovócitos - capazes de "melhorar" a qualidade de seus descendentes, diretos e indiretos.

A Inglaterra, ainda no século XVIII, foi onde se inventou a indústria de "estoque de sangue e pedigree". Segundo a antropóloga Barbara Orland (2004), os saberes da nova escola de economia fisiocrática foram fundamentais para isso. Tal escola propunha reformas para aprimorar a produção do campo, especialmente a pecuária, sugeria o uso de cercas e formação de pastos, plantação de espécimes forrageiras para alimentar os animais e o controle da reprodução através de estações monta e engorda.

É nesse período que um selecionador britânico, Robert Bakewell, desenvolve uma raça bovina pioneira, de carne extremamente macia, que, devido aos seus grandes chifres, ganha a alcunha de Longhorn. Bakewell foi pioneiro no uso do o método de inbreeding no Brasil, "consanguinidade incestuosa" - no desenvolvimento de linhagens de animais de criação - ovelhas, cavalos e bovinos. Através do uso do "sangue" de um mesmo raçador em acasalamentos consecutivos com suas descendentes diretas - filhas, netas e bisnetas esperava que um conjunto de características se mantivesse na linhagem.

Os irmãos Charles e Robert Colling, também selecionadores, seguindo as lições de Bakewell, através de cruzamentos com o tipo Longhorn, desenvolveram outras raças bovinas, Shorthorn, Hereford e Angus, também conhecidas pela maciez de sua carne. Foram os irmãos Colling que selecionaram Comet, da raça Shorthorn, considerado o primeiro bovino "de elite" da história. Através do uso da técnica de inbreeding, promoveram o acasalamento entre o 
touro Favorite e a vaca Phoenix, cuja progênie foi a fêmea Young-Phoenix, que acasalada com seu pai, Favorite, produziu Comet.

Sarah Franklin (2002) defende que Bakewell, através do inbreeding, trouxe um novo conceito à criação e seleção bovina britânica e mesmo mundial. Animais considerados exemplares, ao servirem de modelo para um tipo racial inteiro, passaram a ser comercializados por altas cifras - como Comet, que fora vendido em 1810 em um leilão no vilarejo de Keaton, no leste da Inglaterra, por 1000 libras esterlinas, um recorde de preço para aquele período por combinarem genealogia, propriedade e economia. Segundo a antropóloga, se "indústria de estoque de sangue" trata de linhagens, famílias, pedigrees, raças e, logo, do controle do fluxo de transmissão de substâncias entre ancestrais e descendentes, refere-se a um fundo monetário e financeiro, portanto, a um capital.

É através desta combinação de genealogia, propriedade e economia, sugerida por Franklin, que o mercado de gado "de elite” se realiza na Grã-Bretanha e no Brasil. Mas a “indústria de estoque de sangue” bovino no Brasil, por várias razões, só se consolida pelo menos cem anos mais tarde que na Inglaterra. Se Comet, o primeiro bovino "de elite" do mundo foi vendido por altas cifras já no início do XIX, é só no fim do século passado que reprodutores brasileiros passam a angariar um alto valor de mercado.

\section{Os zebus e os zebuzeiros: um sobrevoo antropozootécnico}

Os trabalhos clássicos de Caio Prado Junior (1941), Capistrano de Abreu (1988), Celso Furtado (1959) e Werneck de Sodré (1941) nos mostram que durante a colônia os bois no Brasil foram usados especialmente para ocupar os sertões. Ao contrário da produção de outros bens, como açúcar, tabaco, ouro, diamante, algodão e café, que sucessivamente foram produzidos para a exportação, a bovinocultura foi durante muito tempo uma atividade voltada ao mercado interno. Apesar de engendrar ciclos econômicos de vulto, como o do couro e das charqueadas, a pecuária bovina brasileira manteve-se "extensiva", por várias décadas.

Isso não indica, todavia, que seleções dirigidas de animais não acontecessem no país. Nas pecuárias mais rudimentares, alguns espécimes, por suas características raciais, eram utilizados e comercializados como reprodutores ${ }^{2}$. Havia algum controle no melhoramento dos rebanhos, mas é somente no alvorecer da República que, de fato, uma "indústria de estoque de sangue" brasileira começa a se consolidar e Uberaba, décadas mais tarde, se torna central na produção de zebus "de elite". 
É na virada do século XIx para o Xx, que o Estado, antes monárquico e em seguida republicano, passou a investir em saberes da ciência aplicada a fim de incrementar a produção do campo (Medrado, 2013; Leal, 2014). Com vistas a aliar o caráter essencialmente agrícola do país com a industrialização, patrocinava a publicação de manuais zootécnicos, inaugurava fazendas experimentais e escolas agrícolas ${ }^{3}$.

Todos esses investimentos, no entanto, especialmente na pecuária bovina, eram efeitos de uma conjuntura política e econômica maior, capitaneada pelas ações da Inglaterra de Bakewell. Se aqui no Brasil a carne bovina, até então, era um produto comercializado e produzido para abastecer o mercado interno, é precisamente na virada do século XIX para o xx que se torna uma demanda alimentar europeia.

A Inglaterra, apesar do domínio de técnicas modernas de seleção e manejo de bovinos - como o inbreeding, o uso de cercas, rações e confinamentos - não tinha terras suficientes para desenvolver uma pecuária voltada ao abastecimento de um mercado mundial de carnes. Além disso, a Primeira Guerra provocou uma escassez de alimentos na Europa. Por essas razões, a Inglaterra, volta seus olhos a novos celeiros alimentares como Argentina e Brasil. Não só passa a fomentar a necessidade de consumo de carne entre suas classes trabalhadoras, como instala frigoríficos nesses países.

Diante dessa nova demanda, coube à elite ganadeira nacional modernizar-se. Era necessário não só, como sugeria Eduardo Cotrim (1913) no primeiro manual zootécnico brasileiro, reformar os edifícios das fazendas (a fim de desenvolver cercas, currais e confinamentos), aplicar cuidados veterinários em seus rebanhos, separar a produção em etapas - cria, recria e engorda - para a reversão da pecuária "selvagem" empreendida até então, mas principalmente avaliar, do ponto de vista zootécnico, quais raças de bovinos eram mais adequadas para abastecer essa emergente indústria de carnes congeladas.

E como Uberaba emerge nesse cenário? O Triângulo Mineiro, conhecido por suas boas pastagens, era desde o século XviII parada de tropeiros que vinham do oeste do país para ali descansar e seguir viagem rumo ao norte e ao litoral a fim de comercializar gado. Era uma passagem, um entroncamento de caminhos. Ligava a sede da colônia às minas de Mato Grosso. Foi por esse caráter de passagem que se tornou, nos séculos seguintes, um importante entreposto comercial.

Foram bois que fizeram o Triângulo se tornar mineiro (Lourenço, 2007). Tropeiros, ao pararem na região que na época pertencia à capitania de Goiás, reclamavam de ter de pagar tributos para comercializar seu gado em Minas Gerais. Por esse motivo, em 1816, o Triângulo 
é anexado a Minas, e em 1836, sua principal centralidade, o antigo Sertão da Farinha Podre, é elevada a vila, nomeada Uberaba décadas depois. Em meados do século xIx, o antigo Sertão da Farinha Podre recebe uma leva de povoamento. Fazendeiros e comerciantes de outras regiões de Minas Gerais, com a decadência da mineração, migram para a localidade. Beneficiados com terras, passam a investir mais sistematicamente na pecuária bovina.

Esses comerciantes e fazendeiros "triangulinos", desde a virada do século XIX para o xx dedicaram-se à compra de gado indiano, o zebu. Primeiramente, na virada do século, trouxeram à Uberaba espécimes zebuínos da província do Rio de Janeiro que eram de propriedade de barões do café fluminenses que os utilizavam para a moenda de grãos. Depois, através de sucessivas e longas viagens à Índia, passaram a importar zebus ao Brasil.

Essas expedições pioneiras à Índia, realizadas ao longo da toda a primeira metade do século xx, em sua maioria capitaneadas por vaqueiros de confiança dos pecuaristas uberabenses, combinadas com a organização dos criadores locais em associações, "sociedades rurais", mas principalmente com o estabelecimento pelos zebuzeiros uberabenses de um conjunto de critérios que definiam o padrão racial e as vantagens zootécnicas dos tipos indianos. Tornaram Uberaba, desde pelo menos a década 30 do século xx, a principal fornecedora de zebus "purosangue", "de elite", utilizados para aprimorar a qualidade dos rebanhos de corte nacionais.

Sobre a história da pecuária zebuína no Brasil, valem mais algumas linhas. Se contemporaneamente mais de $80 \%$ dos rebanhos de corte nacionais são de origem zebuína e os zebus "de elite" brasileiros, os mais caros do mundo, atualmente têm sido clonados, esses tipos foram considerados durante muitos anos "exóticos" e indomesticáveis por mais de uma razão.

$\mathrm{Na}$ Europa, em virtude do tamanho e formato de seus cupins, barbelas e orelhas que os diferiam significativamente dos bovinos de origem europeia, eram expostos junto com camelos em jardins zoológicos. Inclusive foram desses zoológicos que os barões do café fluminenses adquiriram os zebus que eram utilizados na tração (Santiago, 1983). Quando chegaram massivamente no início do século xx ao país pelas mãos dos "triangulinos", houve uma considerável resistência de outras elites ganadeiras, especialmente as paulistas, com esses espécimes (Medrado, 2013). Segundo esses criadores paulistas que, ao investirem em gado europeu disputavam com os "triangulinos" o mercado frigorífico nacional, os zebus eram "indômitos", quase selvagens, sua carne era "dura" e "fétida", portanto, jamais conseguiriam ser domesticados, muito menos utilizados para abastecer a emergente indústria de carnes congeladas.

Coube, então, aos pecuaristas de Uberaba, “zebuzeiros”, purificar suas reses através de uma combinação de iniciativas. Através da publicação de manuais e documentos técnicos, 
criadores e zootecnistas descreviam os zebus como os "verdadeiros bandeirantes brasileiros" (Borges, 1946), os únicos tipos de bovinos capazes de desbravar o sertão de torná-lo habitável. Por comparação com as raças de origem europeia, diziam seus selecionadores, os espécimes zebuínos eram "tropicais" desde a origem, por serem "rústicos" tinham alta tolerância ao calor e às verminoses. Ademais, sua alimentação nos pastos era mais eficiente, conseguiam digerir melhor alimentos grosseiros. Ao requererem menos proteínas e calorias que o gado europeu desenvolvido pelos paulistas, cresciam e engordavam com mais facilidade. Além disso, eram altos, "pernudos", portanto locomoviam-se melhor nas estradas e campos do Brasil Central (Domingues, 1966).

Tal "rusticidade" e capacidade de adaptação aos sertões brasileiros, todavia, não tornava os zebus menos “exóticos” ou “indômitos". Para que os zebus se tornassem modelos - estéticos, reprodutivos, zootécnicos - para a pecuária praticada nos “trópicos”, fez-se necessário enobrecê-los. A publicação regular de pedigrees a partir da década de 30 emitidos pela Sociedade Rural do Triângulo Mineiro (atual ABCZ), produziu efeitos substantivos na maneira como se desenvolveu aqui um mercado de gado "de elite".

O fato é que quando o pedigree entra em cena, os zebuzeiros uberabenses enriquem, conforme sua reses se tornam uma. Mais que exibir o parentesco entre os animais nacionais e importados, organizando assim, através do inbreeding, linhagens e famílias zebuínas, a publicação de pedigrees realizada por esses criadores, consolidou um conjunto de padrões fenotípicos em especial que indicavam "pureza racial". Zebus reprodutores, com pedigree, desde então, passaram a ser comercializados por altas cifras.

Octávio Domingues (1966), considerado como o “patrono da zootecnia tropical” (ver Leal, 2014), dedica algumas linhas para analisar o alto valor de mercado do gado zebu. Sugere que, com vistas a atestar a pureza racial e valorizar seus espécimes para a indústria frigorífica, os zebuzeiros uberabenses estabeleceram um conjunto de critérios, fundamentalmente estéticos, que definiam os animais de procedência mais fina. Estes deveriam ter barbelas, cupins e orelhas protuberantes, todos aqueles atributos corporais que os diferiam, decisivamente, dos bovinos de origem europeia.

Tais características fenotípicas dos espécimes que recebiam pedigree, segundo o zootecnista, não produziam, e de algum modo seguem não produzindo, efeitos na qualidade da carne desses animais (orelhas, cupins ou barbelas não produzem, exatamente, mais peso ou tornam a carne mais macia). Mas, desde os primórdios da pecuária zebuína, teriam despertado nos zebuzeiros, conforme sugere Domingues, um certo "instinto de colecionadores de arte". 
Ávidos em colecionar belos cupins, belas orelhas e belos chifres em seus animais, passaram a não vacilar, como continuam não vacilando, em pagar fortunas por bons reprodutores.

Ademais, em razão da contingência das importações de gado da Índia, que, em virtude de problemas sanitários, ao longo de toda a primeira metade do século xx foram ora proibidas, ora permitidas pelo Estado (Leal, 2014; Medrado, 2013), alguns poucos "pareadores" importados eram de propriedade de algumas poucas famílias de zebuzeiros uberabenses. Estas famílias, envolvidas nas expedições pioneiras, ao estabelecerem os padrões de pureza dos zebus, regulamentavam as leis de oferta e demanda por "raçadores".

Desde então, esta restrita elite de "zebuzeiros" bastante endinheirada e influente politicamente, não só concentra em suas mãos os principais reprodutores que fornecem o conjunto de atributos que fazem a "raça" dos rebanhos de cortes nacionais abatidos, como as dinâmicas de produção do preço e do valor dos zebus “de elite” vendidos por cifras milionárias em suntuosos leilões. Não obstante, atualmente, com vistas a preservar e comercializar a genética e o pedigree é esta elite que está à frente na realização de clonagens de seus animais.

\section{A clonagem de zebus brasileiros}

A Embrapa (Empresa Brasileira de Pesquisa Agropecuária) foi a responsável pelo nascimento do primeiro clone bovino brasileiro: em março de 2001, nasce na fazenda Sucupira, em Brasília - DF, a vaca Vitória, da raça Simental. Experimentos com a técnica de transferência nuclear também vinham sendo realizados por outros centros de pesquisa. Em abril de 2002, através de estudos realizados pela Unesp de Jaboticabal e a Faculdade de Zootecnia e Engenharia de Alimentos da usp, nascem o bezerro Marcolino da usp e, em junho daquele mesmo ano, a fêmea Penta. Em 2003, foi a vez de Bela da usp e de Lenda. No ano de 2005, três outros clones de bovinos foram apresentados.

Criadores de gado "de elite", especialmente de origem zebu, que desenvolvem espécimes "raçadores" utilizados como modelos reprodutivos, estéticos e genealógicos, que aprimoram, especialmente, a qualidade racial do gado de corte, passaram a investir na técnica. Em "parceria" com laboratórios privados e públicos começaram a realizar clonagens de suas reses para fins comerciais.

Um jovem criador de gado Nelore de elite, filho de um parlamentar carioca, destacase no mercado pecuário por ter realizado clonagens em seus bovinos. Durante uma entrevista, narrou o porquê de clonar seus animais: 
Entendendo que a tecnologia de ponta é importantíssima pra seleção, resolvi pegar uma de nossas principais doadoras, a Bilara vII, e cloná-la. Na época esse processo era quase experimental, não se tinha certeza do que ia acontecer. Aí você pode perguntar: "Mas o clone é a cópia fiel do material genético? Não tem melhoramento com o clone?”. Mas a gente queria pegar uma vaca que fosse doadora de embrião e que acasalasse com touros contemporâneos [...]. Porque ela já vinha decaindo a sua produção por conta da idade pra acasalar com futuros touros. Com touros que talvez nem tivessem nascido, touros que nem tivessem disputando as pistas, touros que nem foram campeões. Então hoje a gente tem essa possibilidade, de não só acasalar com os reprodutores atuais. A ideia foi essa, foi uma vaca que entre seus contemporâneos foi um destaque, a ideia era que ela pudesse ser acasalada com animais do futuro.

Aqui vale uma ressalva, que o criador destaca em sua fala. A clonagem, diferentemente de outras tecnologias reprodutivas utilizadas por criadores de gado "de elite", não produz "melhoramento" ou "ganho genético" dos rebanhos. Quando um criador de elite promove o acasalamento entre dois espécimes, tenta gerar uma progênie - na raça, no genótipo e mesmo no fenótipo - superior aos seus pais. As fertilizações in vitro e a inseminação artificial contribuíram decisivamente para isso e, inclusive, são fundamentais para o mercado de gado "de elite" se realizar.

Espécimes "de elite" são considerados como tal por ter uma "conformação racial" exemplar, são belos, simétricos, devem ter pedigree, e, por essas e outras razões, são expostos e julgados em feiras de pecuária e vendidos por cifras milionárias em leilões. Raramente esses animais são abatidos. Seus criadores, ao investirem em "manejo adequado", em registros genealógicos, na participação em eventos agropecuários e na compra destes espécimes em leilões, prospectam produzir animais - "doadoras" ou "raçadores" - cujas células reprodutivas serão utilizadas para "melhorar" a qualidade dos rebanhos comerciais.

São centrais de inseminação artificial e laboratórios que mobilizam boa parte dos lucros do mercado contemporâneo de gado "de elite" brasileiro. Essas empresas são responsáveis pelo comércio de sêmen e "prenhezes". Com uma única ejaculação de um touro, é possível gerar cerca 300 doses de sêmen, utilizáveis através de inseminações artificiais. Para as realizações de fertilizações in vitro, são recolhidos ovócitos - óvulos não maturados que, ao serem misturados com sêmen e mantidos em estufas, transformam-se em embriões e posteriormente em "prenhezes", gestadas nos corpos de vacas "receptoras" (barrigas de aluguel) e comercializadas em leilões. 
O uso de tais tecnologias reprodutivas, segundo criadores e veterinários, foi capaz de alterar substancialmente a pecuária brasileira, qualitativa e quantitativamente. Tanto porque pecuaristas de gado de comum, aquele que é abatido, através de compra de sêmen e embriões, passaram a ter acesso à "genética superior" de espécimes "de elite" - que outrora esteve concentrada nas mãos de poucos criadores -, como porque com essas tecnologias é possível produzir vários espécimes filhos de mesma mãe e do mesmo pai ao mesmo tempo. Em uma monta natural, um touro é capaz de ter no máximo 50 filhos ao ano e uma vaca, apenas uma cria. O uso dessas biotecnologias alterou substancialmente esses números.

Neste sentido, a inseminação artificial e a fertilização in vitro geraram efeitos tanto na pecuária "de elite", quanto na de corte. Parte dos bovinos que compõem os rebanhos comerciais brasileiros, que são abatidos, podem ser descendentes diretos dos espécimes "de elite". Animais encaminhados aos frigoríficos, eventualmente, podem ser filhos, netos ou bisnetos de "raçadores" ou "doadoras de elite".

Além disso, o uso destas biotecnologias é capaz de implodir as fronteiras de tempo e espaço nos traçados genealógicos. Com o uso de células congeladas, é possível produzir acasalamentos entre animais não contemporâneos. Há possibilidade de acasalar reses nascidas recentemente, campeãs atuais dos julgamentos de feiras de pecuária, com espécimes que já faleceram anos atrás.

A produção de animais clonados, apesar de também poder implodir as fronteiras do tempo e do espaço - como defende o criador que afirmou que a genética de Bilara VII, com seus clones, poderia ser utilizada para a realização de acasalamentos com "animais do futuro" -, ainda acontece paulatinamente, por várias razões. Primeiramente, porque a média de êxito das clonagens ainda é pequena se comparada com a das fertilizações in vitro, por exemplo. Cerca de 30\% desses procedimentos geram “embriões viáveis", e, das reses nascidas, apenas 50\% conseguem sobreviver. Há estudos que indicam que clones têm dificuldades no parto e têm a performance como reprodutores reduzida. Ademais, o custo de uma clonagem é relativamente alto e somente os criadores de gado "de elite", na ânsia de replicar seus grandes feitos, investem na biotecnologia.

Clones são cópias. Devem ser idênticos, no genoma, àqueles que doaram as células que deram origem a ele. A antropóloga Carrie Friese (2009) avalia que a clonagem provocou uma alteração substancial na seleção animal. Se antes, através do inbreeding, o objetivo era gerar animais que exibiam certos traços fenotípicos comuns, com a clonagem é possível gerar espécimes com configurações genômicas comuns. Conforme argumenta a autora, tal biotecnologia torna o genoma mais central na reprodução animal do que o fenótipo. 
No caso do mercado de gado "de elite" brasileiro, o fenótipo parece tão elementar quanto o genoma. Como há um conjunto de critérios estéticos, que em parceria com o registro genealógico, determinam a "pureza racial” (a forma dos cupins e da cabeça, a altura das pernas, o arqueamento das costelas, a cor da pele e dos pelos) e, logo, o valor desses animais, criadores de gado de elite não só querem "preservar a genética", como replicar o fenótipo de seus “raçadores” através de processos de clonagem. O pesquisador responsável pela realização da técnica em um laboratório em Uberaba, durante uma entrevista, destacou a semelhança fenotípica dos clones com suas doadoras:

Muito parecido! Muito parecido! É bem próximo! É interessante, claro que a gente ainda não tem um animal adulto, a gente não sabe. Mas, por exemplo, às vezes nascem 4,5 clones do mesmo animal, todos os animais nasceram muito parecidos. A pelagem dos Nelores, apesar de ser branca, tem pelagem vermelha também, é bem avermelhado e vai clareando. Nunca aconteceu de nascer um clone de um mesmo animal vermelho e outro branco. Posição de pinta no mesmo lugar, do mesmo tamanho. Nasceram dois animais agora com a mesma linha escura no rabo, iguais. Nasceram três clones, as manchas vermelhas eram iguais. É interessante observar o pessoal que conhece as doadoras e vem conhecer os animais nascidos, você vê o comentário: realmente é igual ao que nasceu.

No ano de 2007 uma cota ${ }^{4}$ de 50\% da vaca Ópera, um dos clones de Bilara vII, da raça Nelore, foi vendida por um milhão e quarenta reais. Apesar da vaca indubitavelmente poder ser considerada de "elite", já que era a réplica fiel - no genoma e no fenótipo - de uma famosa "doadora", não recebeu pedigree.

$\mathrm{Na}$ época, a Associação Brasileira dos Criadores de Zebu não tinha instrumental para lidar com as controvérsias que Ópera mobilizava. Indubitavelmente ela corporificava padrões de excelência de sua raça, mas, como os critérios que fundamentavam a publicação de pedigrees estavam baseados na influência e registro de dois genitores, pai e mãe, e consequentemente avôs e bisavôs, a clonagem de bovinos gerou um "vácuo regulatório". Quem eram, de fato, os pais de Ópera? De certo ponto de vista, Bilara viI pode ser pensada como a "irmã" de Ópera, de outro, como a "mãe". Mas quem seria seu pai?

A ovelha Dolly e a vaca Ópera têm uma trajetória genealógica comum. Como enfatiza Franklin (2007), Dolly provocou um abalo nas ideias naturalizadas de gênero, sexo e mesmo raça ou espécie. A união de gametas de indivíduos de diferentes sexos, que outrora foi considerada 
elementar para a concepção e geração da progênie é colocada à prova em processos de clonagem. Dolly e Ópera são efeitos de uma reprodução capaz de incluir somente fêmeas: a doadora do ovócito, a fêmea que foi clonada e a barriga de aluguel que a gerou.

Vale pensar que Ópera e Bilara são geneticamente idênticas e que a Associação Brasileira de Criadores de Gado Zebu fundamenta muitas de suas políticas na ideia de genética. Mas o "vácuo regulatório" na definição dos pedigrees dos clones de bovinos zebus brasileiros ajuda a pensar, como bem lembra Strathern em After Nature (1992), que o parentesco não se esgota nas substâncias biogenéticas.

\section{Os clones, o pedigree, o parentesco e o valor do gado e dos criadores de elite}

As controvérsias envolvendo o registro genealógico de Ópera, clone de Bilara VII, incitam uma análise não só sobre a replicação destes espécimes, mas sobre a centralidade dos pedigrees para o mercado de zebus "de elite" brasileiros. O que está implícito nesses registros, além de um padrão de excelência racial e das linhas de ascendência e descendência que transmitem atributos hereditários? Como pedigrees produzem o valor, e também a forma preço, desses animais?

Há um tema discutido por alguns antropólogos que pode iluminar explicações sobre o valor, e mesmo a forma preço, de bovinos “de elite" brasileiros: a diferença entre pedigree e genealogia. Para Barnes (1967) as genealogias são registros de relações de parentesco construídas pelos analistas a partir de um certo rigor metodológico; já os pedigrees são informações destes mesmo termos elaboradas pelos próprios nativos.

Tim Ingold (2007) dá atenção às linhas genealógicas e desenvolve esse argumento de Barnes. Para ele, a leitura do traçado de um pedigree funciona como uma espécie de itinerário, um passeio pelas curvas de um rio. Os personagens elencados nestes traçados genealógicos funcionam como os locais ou coisas achados nesse passeio, ajudam a narrar a história desse trajeto, reconstroem a memória de uma jornada. As leituras das genealogias construídas pelos antropólogos, prossegue o autor, são capazes de montar uma estrutura de fragmentos bastante congruente, mas não são necessariamente caminhos que passam pela memória. Os indivíduos, representados por triângulos e círculos, reconstroem o enredo de linhas conectoras de ancestrais e ascendentes. Lidas de baixo para cima, as genealogias conectam pontos de uma página e branco e indicam as posições específicas que os indivíduos ocupam em um modelo mais geral. 
$\mathrm{Na}$ mesma direção, ao analisar os investimentos feitos por antropólogos ingleses em estudos de parentesco, Mary Bouquet (1993) lembra que a técnica de coletar genealogias, inaugurada por Rivers, é uma maquinaria da antropologia social britânica. Por isso Bouquet entende o método genealógico como um artefato, resultado da imposição primordial de substância material que conta histórias sobre sobrevivência cultural e emergência. Já o pedigree, prossegue a autora, é um instrumento capaz de identificar algumas teorias não inscritas no vocabulário técnico do parentesco. A crítica de Bouquet é a de que as ideias de pedigree e genealogia passaram a ser utilizadas como termos intercambiáveis, sem serem devidamente problematizadas pelos antropólogos.

Fundamentado no princípio teórico de reconhecer descendência a partir das linhas maternas e paternas como critério de pertença a um grupo familiar específico, a dinastias ou mesmo a nobreza, o pedigree teria origem na seleção dirigida de animais, na qual o controle sobre a reprodução e a hereditariedade é implícito: o caráter aristocrático do sangue é mais que uma metáfora. Os pedigrees, para Bouquet, diferentemente das genealogias, fazem espécimes - sejam eles humanos ou animais - com distinção.

É certo que, em virtude do uso de tecnologias reprodutivas, muitos zebus brasileiros, mesmo aqueles encaminhados aos frigoríficos, não só são descendentes - filhos, netos ou bisnetos - de espécimes "de elite", como podem ter os mesmíssimos progenitores. Alguns bovinos, inclusive, podem ter a mesma genealogia que aqueles como Bilara VII, com um alto valor de mercado. Mas genealogias, isoladamente, não os fazem competir nas pistas de julgamento de feiras agropecuárias, tampouco que sejam vendidos por cifras milionárias, ou seja, não os tornam “de elite". Ter a mesma mãe, o mesmo pai, o mesmo avô ou mesmo ser irmão de um espécime muito prestigiado na pecuária zebuína brasileira não garante, necessariamente, um pedigree.

Espécimes "de elite" compartilham com seus descentes e ascendentes um conjunto de atributos hereditários que conformam uma raça, um padrão específico. É por essa razão que a $\mathrm{ABCZ}$ emite certificados de registro genealógico e esse mercado, através de tecnologias reprodutivas, mobiliza altas cifras. Mas vale pensar que um espécime "de elite" também é efeito de uma autoria, do trabalho de alguns selecionadores, em realizar acasalamentos dirigidos, que não só produzem esses animais raros, especiais, com um alto valor de mercado, mas que evidenciam o saber desses criadores em selecionar.

A habilidade em selecionar zebus é um valor em si mesmo, difícil de ser descrito por aqueles que pouco frequentam leilões, feiras e julgamentos. Um talento que só é conhecido 
e apreciado, de fato, por outros zebuzeiros que executam esse mesmo ofício. Há quem diga, inclusive, que um bovino "de elite" tem o valor de seu criador. Se poucos bovinos conseguem corporificar o conjunto de atributos necessários para serem considerados como tal e também por isso são vendidos por cifras milionárias, poucos são os selecionadores capazes de fazê-los não só como fornecedores de raça aos espécimes de corte, mas enquanto deleites estéticos.

Há um saber em selecionar que não está em manuais de zootecnia e que é o que torna um criador, de fato, um criador, dizem os zebuzeiros. Segundo alguns pecuaristas, tal talento não se ensina ou se aprende, está "no sangue". Por isso, há uma certa escassez que rege a lei de oferta e demanda por criadores e bovinos no mercado de gado "de elite" brasileiro, e que, não obstante, é elementar na feitura de pedigrees.

Desde as primeiras importações de gado da Índia na virada do século XIx para o Xx, algumas poucas famílias de zebuzeiros, proprietários dos principais reprodutores, estão nesse mercado fazendo bois "de elite" e se produzindo enquanto notórios e prestigiados criadores. Esses pecuaristas que conhecem e produzem pedigrees bovinos, ao concentrar e apurar o "sangue" de seus animais, também produzem seus próprios pedigrees e seu próprio "sangue".

Famílias de zebuzeiros, há algumas gerações, através de restritas trocas econômicas - de bovinos e de bastante dinheiro -, mas também através de alianças matrimoniais, têm se organizado como uma elite e, desse modo, tornado seus bois como tal. Não só concentram e apuram o "sangue" que torna um bovino "raro", excepcional, com pedigree, mas ao controlar o fluxo de seu próprio sangue, através dos usuais casamentos entre filhos e netos de zebuzeiros tradicionais, concentram em suas próprias linhagens a substância (o sangue) que os tornam exímios entendedores de gado.

Um zebu "de elite" é, indubitavelmente, influenciado por seus criadores através de manipulações genéticas e de uma intenção que é simbólica: produzir um espécime que é único e servirá como um modelo que é tanto biogenético, quanto genealógico e estético. Esse conjunto de relações e intenções produz o valor desses espécimes e é por isso que pedigrees corporificam memórias e traços de distinção desses bois, mas também de seus criadores.

Narradores de leilões, por exemplo, com vistas a aquecer os preços de um pregão, lembram a semelhança dos animais com seus pais, avôs e bisavôs e as substâncias que certamente serão capazes de prover as gerações futuras. Mas nessa narrativa genealógica há algo que vai além das relações de descendência e ascendência, porque outras genealogias são acionadas nessas ocasiões. Como bovinos e criadores são indissociáveis nesse mercado, quando se fala da mãe de determinado espécie, também é lembrada a trajetória de quem a criou. 
Um conhecedor desse mercado facilmente consegue se lembrar de quem são os criadores das reses mais prestigiadas, inclusive, esta informação é escrita nos registros genealógicos da ABCZ e marcada a ferro em brasas nos corpos dos bovinos. Ao compor o pedigree de um animal, concomitantemente, há a composição de uma genealogia dos criadores dessas reses. Neste sentido, um "espécime de elite” opera como repositório que mistura e simetriza influências, reputações e genealogias bovinas e humanas.

Mas como produzir a univocidade ou raridade de cópias, como são os clones? Há mesmo uma autoria dessas reses? Quem, de fato, seriam os autores desses espécimes? A doadora de células que deu origem a ele? O criador da doadora? O técnico de laboratório que realizou o procedimento de clonagem? Mais que isso, a clonagem de bovinos brasileiros estaria em vias de alterar as dinâmicas de produção de influências entre reses e bovinos que produzem o valor, a forma preço e também o pedigree? Clones, por serem réplicas, teriam o mesmo valor que os espécimes "de elite" que os originaram?

\section{Os pedigrees dos clones}

No mesmo ano em que Ópera foi comercializada por cifras milionárias, a então senadora pelo PMDB Kátia Abreu, publicou um projeto de lei para regulamentar as atividades de pesquisa e comércio de clones de mamíferos. A lei 73/2007, já foi tramitada em comissões de ética da Câmara e no Senado, mas ainda não está em vigor.

$\mathrm{Na}$ justificação da lei, inclusive, há um trecho que ressalta que a clonagem de bovinos de elevado mérito genético já acontecia mesmo sem regulamentação no Brasil. A senadora escreveu que "pioneiros" não só estariam clonando seus animais, como criando empresas especializadas na técnica. E essa era uma das principais razões para a normatização da clonagem no país.

Foi somente três anos após a venda de Ópera, em 2011, que a Associação Brasileira dos Criadores de Zebu concedeu o primeiro pedigree a um clone zebuíno. O animal, uma cópia da doadora Divisa Mata Velha, inclusive, era de propriedade de um criador, vicepresidente da associação, que no período montava seu laboratório de clonagem na cidade de Uberaba. Em "parceria” com os pesquisadores da Embrapa que fizeram Vitória, contratados pelo criador, e com financiamento do BNDES e contribuição de bolsistas da Capes e do CNPq, o laboratório já vinha se destacando no mercado da clonagem. 
Para a concessão do registro genealógico dos clones, a ABCZ, em parceria com o Ministério da Agricultura, estabeleceu um protocolo. O pedigree só seria concedido aos 18 meses de idade, momento em que bovinos de origem indiana são considerados adultos. Nesta idade costumam apresentar os caracteres que definem os padrões fenotípicos e zootécnicos de sua raça, além disso, é quando suas habilidades como reprodutores podem ser atestadas. Os clones passaram a ter o mesmíssimo pedigree do indivíduo que deu origem a ele, mas à sigla alfa numérica que identifica seu registro genealógico na ABCZ, é acrescida das letras TN, que indicam que ele foi produzido a partir da biotecnologia de transferência nuclear.

Além disso, tanto a "doadora" do ovócito que dará origem ao clone, quanto a “receptora” que o gestará devem ser da mesma raça. E todos os três animais (a doadora, o clone e a barriga de aluguel) devem ser submetidos a exames de DNA. Ademais, a propriedade intelectual do clone, mesmo quando comercializado, é do criador do animal que doou as células que originou aquela cópia, do sujeito que quis replicar a genética (e a estética) de certo indivíduo de seu rebanho.

Interessante pensar que depois dos procedimentos bem-sucedidos de transferência nuclear com células de Bilara VII, de Divisa Mata Velha e de concessão de registros genealógicos pela ABCZ, outros clones, além de Ópera, já foram comercializados em leilões de elite no Brasil, mas eles nunca alcançaram o preço de suas doadoras. Talvez porque a clonagem, de certo ponto de vista, ainda é experimental no Brasil (não há certeza absoluta sobre o futuro desses animais); ou, por outro lado, porque clones são mesmo "cópias", réplicas.

O estatuto de réplica implica repensar não só a forma preço, mas especialmente o valor dos clones enquanto uma mercadoria rara, especial, "de elite". Como lembra Walter Benjamin (1955), as réplicas no mercado da arte incitam reflexões acerca da ideia de autenticidade e originalidade e mesmo da relação entre artista, obra e técnica. No caso do mercado de gado "de elite" brasileiro, que se fundamenta, como o mercado da arte, numa ideia de autoria, criação e mesmo de estética, a raridade ou univocidade - da genealogia, da conformação racial, da beleza, do saber do criador - que simetriza e vincula homens e bois, e que, não obstante, ajuda a justificar os preços milionários dos animais "raçadores" nos leilões, parece estar corporificada nos doadores de células, e não nos clones.

Mas há ainda muitas outras controvérsias na clonagem de bovinos no país que produzem efeitos para além deste restrito mercado, de elite, produtor de pedigrees, leilões e cifras milionárias.

Carlos Martins (2011), um pesquisador da Embrapa, ao defender a regulamentação dos processos de transferência no Brasil, descreve que estudos desenvolvidos pela EFSA 
(European Food Safety Autority), uma instituição que controla a segurança alimentar na Europa, apontaram que não há diferença na qualidade da carne e do leite produzido pelos clones. Segundo Martins, estes estudos demonstraram que produtos de clones são passíveis de serem consumidos por humanos.

A mesma EFSA, no entanto, deliberou que clones e os produtos derivados deles não poderiam ser comercializados na Europa. Se no Brasil clones de bovinos já são vendidos em leilões, na Europa são produzidos exclusivamente para fins experimentais. Na Nova Zelândia, que também é referência na produção de clones, ocorre situação parecida. Recentemente, através de pesquisas com clonagem e transgenia, foi feita a vaca Daisy, o primeiro bovino do mundo a produzir um tipo de leite cuja composição não contém a proteína que afeta humanos alérgicos a lactose. Apesar dos benefícios que este leite pode supostamente trazer, o comércio de produtos oriundos de clones também é proibido naquele país e os investimentos neste tipo de pesquisa foram cessados.

Criadores de gado "de elite", cientistas, mas também políticos brasileiros, como a senadora Kátia Abreu, têm visto esse cenário internacional de cessão de pesquisas com clones com muito bons olhos. Prospectam a possibilidade de tornar o Brasil, que já é um dos maiores produtores de carne bovina e vende os zebus de elite mais caros do mundo, a principal referência na clonagem destas reses.

O veterinário responsável pela tecnologia de transferência nuclear de bovinos de um laboratório de Uberaba, avaliou este cenário de produção de bovinos clonados no mundo:

Pra você ter ideia, no início do ano passado eu fui à Nova Zelândia, tem um pesquisador lá que foi o segundo no mundo a clonar um animal, o primeiro foi o Wilmut lá na Escócia, até fez doutorado com ele. Ele trabalha desde 96 com clonagem, a gente entrou em contato e eu passei uns dias com ele lá. Ele trabalha num centro de pesquisa igual a Embrapa, só que na Nova Zelândia eles tão parando com a clonagem. Então, se ele produzir um clone, não vai conseguir congelar sêmen e vender porque não pode comercializar nada dele. Como ele trabalha pro Estado e a população não quer, ele vai mudar a área de trabalho. O que está acontecendo no Brasil hoje é muito diferente. É uma tecnologia nova que a população em geral não conhece, acha que é coisa de outro mundo, associa muito com transgênicos, que hoje ainda não tem nada a ver, você pode até usar a clonagem pra fazer transgenia, mas você pode fazer transgenia de outras formas completamente diferentes. Clonagem no começo era aquele negócio: "Você tá brincando 
de Deus". Gente, é uma técnica reprodutiva como qualquer outra técnica de reprodução assistida. Hoje em humano também se usa isso. Olha o tanto de bebê de proveta que tá nascendo assim. A clonagem é a mesma ideia, só que você usa células diferentes.

\section{Considerações finais}

Por ora, a tecnologia de transferência nuclear parece ser a última fronteira alcançada pelo mercado de gado "de elite" brasileiro. Se a clonagem de zebus, do ponto de vista biotecnológico, é inovadora segundo seus criadores, já que permite a replicação de espécimes de elevado "mérito genético" como são os espécimes "de elite”, de outra perspectiva ajuda a elucidar velhas relações entre Estado e empresariado rural no Brasil.

Moacir Palmeira (1999) lembra que junto com a modernização rural, que através da tecnificação e mecanização da produção colocou o Brasil em circuitos de comercialização de matérias-primas e alimentos para exportação, surge a fábula do "empresário rural moderno": o homem do campo que acessa tecnologias ou mesmo o empresário de outros ramos que passa a investir na agropecuária. O que essa fábula não explica, segundo o antropólogo, é de que maneira o Estado atua para a permanência desses empresários nesse setor. Ressalta que os documentos governamentais e mesmo os acadêmicos costumam tratar Estado e empresariado rural como entidades estranhas e quando essa relação é pensada, é vista em termos de representação e influência.

Segundo Palmeira, essas análises não notam que entre Estado e empresariado há uma “coalização de interesses”. Para o antropólogo, não são exatamente legisladores ou relações de clientelismo que pautam a demanda do setor, mas lobistas, órgãos públicos. O Estado, nesse sentido, mais que o regulador do mercado agropecuário, é a condição que garante a existência do empresariado rural.

Os processos de clonagem de bovinos "de elite" brasileiros são exemplares para pensar com Palmeira. Não foi preciso que uma lei regulamentasse os procedimentos de transferência nuclear de bovinos para que eles acontecessem, apesar das controvérsias que geraram. Mais que normatizar o uso de tais biotecnologias, o projeto de lei de Kátia Abreu, leva para discussão no Senado e na Câmara uma demanda, de um grupo bastante restrito, indubitavelmente, como seus bois, "de elite”, que já está pronta. O Estado, nesse sentido, 
mais que normatizar, é quem viabiliza, através de "parcerias" com universidades públicas, empresas de pesquisa agropecuária, ministérios, bancos de desenvolvimento, os processos de transferência nuclear de bovinos no Brasil.

Os laboratórios e criadores de gado "de elite" que produzem e comercializam clones, através de sua associação, estabeleceram seus próprios protocolos. Os pedigrees desses espécimes emitidos pela $\mathrm{ABCZ}$ continuaram elucidando a estreita relação entre criadores e bovinos "de elite" que produz o valor desses espécimes, apesar das réplicas terem um menor preço de mercado. A propriedade intelectual dos clones, que fica a cargo do criador do animal doador de células é um efeito disso, mantém a concentração de saber, influências, mas também de divisas financeiras nas mãos de tradicionais famílias de pecuaristas que há pelo menos um século selecionam zebus reprodutores.

Resta saber que outros efeitos a clonagem de bovinos pode vir produzir, para o restrito mercado de gado "de elite” brasileiro e para além dele. Mas isso é tema de outras conversas ${ }^{6}$.

\section{Notas}

${ }^{1}$ Zebu não é uma única raça como muitas pessoas podem vir a pensar, mas uma das denominações ao conjunto de bovinos de origem indiana, da subespécie Bos taurus indicus. Nelores são zebus assim como espécimes das raças Gir, Guzerá, Brahman, Indubrasil, entre outras. A presença de cupim nesses animais, além, é claro, da origem, indiana, é uma de suas características raciais mais notáveis. O naturalista Charles Darwin trata disso no capítulo primeiro de Origem das Espécies (1859), descrevendo as diferenças fenotípicas entre esses tipos e os bovinos europeus. O nome zebu, inclusive, faz referência aos cupins, é uma corruptela do termo na língua castelhana, cebu, que alcunha os bois com cupim.

${ }^{2}$ Caio Prado Junior, ao descrever as três zonas da pecuária brasileira que se desenvolveram durante a colônia - os sertões do norte, as planícies do sul do Brasil e a parte meridional de Minas Gerais -, destaca que nessa última incrementou-se uma bovinocultura mais elaborada. Ao contrário de seus congêneres sulistas e nordestinos, os mineiros, desde muito cedo, utilizavam cercas, tapagens e formação de pastos em suas propriedades. Isso tanto ajudou na produção de leite - que era utilizado para a produção de manteigas e queijos para o Rio de Janeiro - quanto de reprodutores, comercializados inclusive para o nordeste, a zona criatória mais extensa e antiga da colônia.

${ }^{3}$ É neste período, por exemplo, precisamente no ano de 1877, que é fundado o Instituto Agronômico de Campinas, posteriormente, transformado, em 1892, na Esalq (Escola Superior de Agricultura Luiz de Queiroz). A inauguração da Sociedade Brasileira de Agricultura, em 1887, foi fundamental para o surgimento de uma pasta para tratar do tema, o Ministério da Agricultura, Indústria e Comércio de 1909. Além destes, vale mencionar como fundamentais para a guinada da pecuária brasileira, três documentos, de nome Monografias agricolas (1903), em que Joaquim Travassos avalia o gado nacional, e a publicação do primeiro manual zootécnico brasileiro, A faženda moderna (1913), de Eduardo Cotrim. 


\begin{abstract}
${ }^{4}$ Animais "de elite" podem ser comercializados em leilões em cotas de 25\%, 50\% e 70\%. Criadores se associam para adquirir esses animais e, assim, dividir os lucros da venda de sêmen ou de embriões de "raçadores" ou "doadoras" através das centrais e laboratórios.
\end{abstract}

${ }^{5}$ Há toda uma literatura antropológica nacional (Marques, 2002; Woortman, 1995; Comerford, 2003; Vander Velden, 2004) e estrangeira (Carsten, 2013; Schneider, 1980; Strathern, 1999; Cassidy, 2002) sobre o potencial transformativo e analítico da ideia de sangue. $O$ fato é que o sangue, que pode ser pensado tanto como uma substância, quanto um símbolo, como parte da pessoa e um objeto que pode ser comercializado, é central na pecuária de gado "de elite" brasileira, tanto para pensar bois, como homens. Em minha tese de doutorado, há um capítulo dedicado a pensar essa substância que relaciona as genealogias e os atributos de zebus e zebuzeiros, e que não obstante, é essencial, para conformá-los enquanto uma elite (Leal, 2014).

${ }^{6}$ Uma primeira reflexão sobre a clonagem no mercado de gado "de elite" brasileiro foi apresentada no III Seminário de Antropologia da UFSCar. Gostaria de agradecer pelos comentários do Grupo de Trabalho "Símbolos e Sujeitos: Diálogos antropológicos sobre as interações entre humanos e animais" e pela leitura atenta de Samantha Gaspar da última versão desse artigo.

\title{
Referências bibliográficas
}

Abreu, João Capistrano de

[1907] 1988 Capitulos de história colonial. Belo Horizonte, Itatiaia/São Paulo, Edusp.

BARnes, Jonh Arundel

1967 "Agnation among the Enga. A Review Article". Oceania, v. 38: 33-43.

BENJAMIN, Walter

[1955] 1994 "A obra de arte na era de sua reprodutibilidade técnica". In

Magia e técnica: ensaios sobre literatura e história da cultura. Tradução de Sergio

Paulo Rouanet. São Paulo, Brasiliense.

BOUQueT, Mary

1993 Reclaiming English Kinship. Manchester, Manchester University Press.

CARSTEN, Janet

2013 Blood Will Out: Essays on Liquid Transfers and Flows. Willey, Journal Royal Anthropological.

\section{CAssidy, Rebecca}

2002 The Sport of Kings. Kinship, Class and Thoroughbred Breeding in Newmarket. Cambridge, Cambridge University Press 
COTRIM, Eduardo

1913 A fazenda moderna. Bruxellas, Typographa V. Verteneuil \& L. Desment.

DARWIN, Charles

[1857] 2002 Origem das espécies. Belo Horizonte, Editora Itatiaia.

Domingues, Octávio

1966 O gado nos trópicos. Rio de Janeiro, Instituto de Zootecnia, Projeto ETA n.27, Série Monografias, 4.

INGOLD, Tim

2007 “The Genealogical line”. In Lines, a Brief History. Londres/Nova York,

Routledge.

FRANKLIN, Sarah

2007 Dolly Mixtures. The remaking of genealogy. Durham, Duke University Press.

2002. "Dolly's Body: Gender, Genetics, and the New Genetic Capital". In KaLof, L. e Fitzgerald, A (orgs). The Animals Reader: The Essential Classic and Contemporary Writings. Oxford e Nova York, Berg, pp. 349-361.

Friese, Carry

2009 "Models of Cloning, Models for the Zoo: Rethinking the Sociological Significance of Cloned Animals". BioSocieties, 4 (4): 367-399.

Furtado, Celso

[1959] 2007 A formação econômica do Brasil. São Paulo, Companhia das Letras.

LATOUR, Bruno

2003 Jamais fomos modernos. Rio de Janeiro, Ed.34.

Leal, Natacha Simei

2014 Nome aos bois. Zebus e zebuzeiros em uma pecuária brasileira de elite. São Paulo, tese, USP.

Lourenço, Luiz Gustavo Bustamante

2007 Das fronteiras do império ao coração da república. São Paulo, tese, usP. 
Martins, Carlos

2011 Perspectivas da clonagem de bovinos para a pecuária. Planaltina, Embrapa Cerrado, 2011. Disponível em: <http://www.cpac.embrapa.br/noticias/artigosmidia/ publicados/349/>. Acesso em: 08 nov. 2013.

Marques, Ana Claudia Rocha

2002 Intrigas e questões. Tramas sociais no sertão de Pernambuco. Rio de Janeiro, Relume Dumará.

Medrado, Joana

2013 Do pastoreio à Pecuária. A invenção da modernização rural nos sertões do Brasil Central. Niterói, tese, UFF.

ORLAND, Barbara

2003 "Turbo Cows: 'Producing a Competitive Animal in the Nineteenth and Early Twentieth Centuries", In Schrepfer, S R. e Scranton, P. (orgs.), Industrializing Organisms. Introducing Evolutionary History. Nova York e Londres, Routledge, pp. 167189.

Palmeira, Moacir

1989 “Modernização, Estado e Questão Agrária”. Estudos Avançados, v. 3, n.7: 87-108.

Prado JR., Caio

[1942] 2010 A formação do Brasil contemporâneo. São Paulo, Companhia das Letras.

SCHNeIDER, David

1968 American Kinship. A Cultural Account. Chicago, The University Chicago Press.

Santiago, Alberto Alves

1983 O Nelore. São Paulo, Editora dos Criadores.

SILVA, Alexandre Barbosa

1947 O Zebu na Índia e no Brasil. Rio de Janeiro, S. Ed.

STRATHERN, Marylin

1999 After Nature. English Kinship in the Late Twentieth Century. Cambridge, Cambridge University Press. 
SODRÉ, Nelson Werneck

1941 Oeste: ensaio sobre a grande propriedade pastoril. Rio de Janeiro, Olympo.

Travassos, Joaquim Carlos

1903 Monografias Agrícolas. Vol. 1 Gado Vaccum. Ezoognozia e aptidões econômicas de cada raça. Rio de Janeiro.

VAnder Velden, Felipe Ferreira

2004 Por onde o sangue circula: os Karintiana e a intervenção biomédica. Campinas, dissertação, Unicamp.

WALTON, Jonh

1999 "Pedigree and Productivity in the British and North American Cattle Kingdoms before 1930”. Journal of Historical Geography, v. 4: 441-462.

WiLmut, Ian e Tudge, Colin

2000 Dolly, a segunda criação e a era do controle. São Paulo, Editora Objetiva.

Wilmut, Ian; Schnieke, A.E.; Mcwhir, J.; Kind, A.J.; e CAmpbell, K.H.S.

1997 "Viable Offspring Derived from Fetal and Adult Mammalian Cells". Nature, 385: 810-813.

WOORTMANn, Ellen

1995 Herdeiros, parentes e compadres. Brasília, Hucitec/Ed. unB. 


\title{
Zebus and Its Clones: Value and Pedigree in an Elite Cattle Market
}

\begin{abstract}
Brazil sells the most expensive zebu "elite" cattle - racial, aesthetic and reproductive models - of the planet. Through "partnerships" between farmers and laboratories, is ahead in the use and research of biotechnologies (artificial insemination, in vitro fertilization, cloning) to produce these animals. In 2002, Embrapa conducted a successful nuclear transfer procedure. Since then, farmers that invested in experimental research on nuclear transfer, started to produce and market important breeding clones. In 2007, a clone of Bilara VII, Opera, was sold for one million at an auction. Despite the high price paid by the animal, it cannot receive pedigree; at the time, nor the Brazilian Association of Zebu Breeders (institution that controls the racial standards and providing genealogical records of zebu specimens in Brazil), nor the Ministry of Agriculture were able to deal with the controversies that Opera mobilized: undoubtedly she was an "elite" cow, but who were, in fact, their parents? This article, from an anthropological perspective, by describing the controversies surrounding the first nuclear transfer procedures and cloned cattle trade - by laboratories and auctions - aims to light up the production and realization of the Brazilian elite cattle market. Wants to think about the centrality of pedigree idea in zebu livestock, the effects of the use of reproductive technologies, the coalition of interests between rural entrepreneurs and state in Brazil and reflect on the status and value of elite cattle and farmers.
\end{abstract}

KEYWORDS: Agribusiness, Cloning, Elite, Livestock, Pedigree.

Recebido em outubro de 2015. Aceito em abril de 2016. 